\title{
Proteoglycans in different mineralization stages of bovine alveolar bone
}

\author{
Takao Kubota \\ *Department of Orthodontics, **Department of Oral Biochemistry, Kanagawa Dental College, \\ 82, Inaoka-cho, Yokosuka, Kanagawa, Japan \\ (Chief: Prof. Yoshii Suzuki*, Shigeru Saito**)
}

[Accepted for publication: December 12, 1984]

Key words: alveolar bone / proteoglycan / density / mineralization

\begin{abstract}
A density fractionation procedure has been used to study the characteristic proteoglycans of bovine alveolar bone at different degrees of mineralization. Bone powder fractions were extracted with $4 \mathrm{M}$ guanidium chloride $(\mathrm{GdmCl})$ and subsequently demineralized with $0.5 \mathrm{M}$ ethylenediamine tetraacetic acid (EDTA) containing protease inhibitors. Alveolar bone powder was distributed into density fractions from 1.8 to $2.1 \mathrm{~g} / \mathrm{cm}^{3}$. The amount of non-collagenous proteins markedly decreased with increasing density. Hexuronic acid content was also decreased with increasing density. Chromatographic analysis of the proteoglycans indicated three species of proteoglycans in these extracts. A large proteoglycan, present only in $\mathrm{GdmCl}$ extract (corresponds to non-mineralized region), diminished with increasing density. A relatively small proteoglycan was present in both $\mathrm{GdmCl}$ and EDTA extract (mineralized region). The amino acid composition and immuno reactivity of each small proteoglycan was similar. Yet, all three proteoglycans were cross-reactive with anti-small proteoglycan. These data suggest that the decrease of proteoglycan and the change of its size is related to the mineralization process in bone.
\end{abstract}

\section{Introduction}

It is one of the most important problems underlying much of dental practice to understand the processes of apposition and resorption of bone tissue, especially those of alveolar bone. Those functions are dependent on the physicochemical properties and interaction of the macromolecular components of the tissue. The macromolecular components of bone can be divided into two broad classes; type I collagen and non-collagenous proteins. Recent studies have been focussed on the non-collagenous proteins, because the chemical and metabolic characteristics of these constituent may be the key regulatory factors in the mineralization of bone ${ }^{1,2)}$.

Proteoglycans are among the major noncollagenous proteins of extracellular matrix and have long been implicated in the regula- tion of hydroxyapatite formation and growth in the process of cartilage calcification ${ }^{1,3}$.

Earlier concepts had proteoglycans of bone as being similar to those of cartilage. Little information is available regarding the nature of the intact bone proteoglycans. In the last few years, a sequential extraction procedure using proteolytic inhibitors and dissociating solvents was developed ${ }^{4,5)}$. Several investigators showed the structure of intact proteoglycans. According to Fisher et $a l^{6)}$, two distinct proteoglycan species existed in fetal diaphyseal bone; a large $\left(\mathrm{Mr}-10^{6}\right)$ proteoglycan and a small $\left(\mathrm{Mr}-10^{5}\right)$ proteoglycan, which showed distinct differences from cartilage proteoglycan in size. Also, Sato et al. ${ }^{7)}$, found a major small proteoglycan of bovine compact bone, which existed in the formic acid precipitate of an EDTA extract. The functions and the relationship to the mineralization process of bone proteoglycan are 
not well understood.

Earlier microradiographic studies have demonstrated by osteons (functional units of bone) of different mineralization degrees. The isolation of these osteons can be investigate bone matulation changes within a bone. The density fractionation procedure can separate the osteons of different mineralization degrees. The aim of the present investigation is to determine the quantity and quality change of bone proteoglycan during the mineralization process, using this procedure.

\section{Materials and Methods}

\section{Preparation of bone samples}

Mandibular alveolar bones were taken from 2-4 years old bovine animals. Bones were scraped clean of soft tissue, and then, cut into small pieces which were placed in a cold phosphate buffered saline (PBS) of protease inhibitors. Cleaned bones were defatted with acetone and then dried under vacuum and stored at $-20^{\circ} \mathrm{C}$ until used. The bone samples were ground into a fine powder in a liquid nitrogen-bathed percussion hummer mill (Spex Int. Model 6700 freezer mill, Metuchen N.J.). The bone powder was sieved through standard testing sieve of mesh size 400 in order to obtain homogeneous particles. The bone was reduced to a $1-10 \mu \mathrm{m}$ particle size range (average $5 \mu \mathrm{m}$ ) as determined microscopically.

2. Fractionation of bone in different mineralization stages

Fractionation of bone powder was carried out by a modification of the method described Richelle ${ }^{8)}$ and Roufosse ${ }^{9,10)}$ using step-wise centrifugation in bromoformtoluene mixtures spanning a range of densities from 1.8 to $2.1 \mathrm{~g} / \mathrm{cm}^{3}$. This was carried out as follows; $3.0 \mathrm{~g}$ ground whole bone powder was put in a centrifugation tube to which was added $50 \mathrm{ml}$ of a $1.8 \mathrm{~g} / \mathrm{cm}^{3}$ density solution. Density was determined by a standard hydrometer which was adjusted to a sensitivity of $\pm 0.002 \mathrm{~g} / \mathrm{cm}^{3}$. The tube was capped, shaken, and sonicated to obtain a homogeneous suspension of bone powder in the fluid. The solution was centrifuged for $30 \mathrm{~min}$ at $10,000 \mathrm{rpm}$ (HITACHI 18PR-III) at room temperature. After centrifugation, the supernatant containing the fraction of the sample with a specific gravity equal to or lower than $1.8 \mathrm{~g} / \mathrm{cm}^{3}$ was removed. This operation was repeated 2 times. Then what was left of the sample was washed with ethanol, dried and resuspended in the liquid of specific gravity $1.9 \mathrm{~g} / \mathrm{cm}^{3}$. The procedure was repeated until the sample had been transferred through an adequate series of liquids, generally ranging from 1.8 to $2.1 \mathrm{~g} /$ $\mathrm{cm}^{3}$. The percentage distribution of the various bone density fractions in a sample of whole bone powder was calculated.

\section{Extraction of alveolar bone}

The separated bone powders were sequentially extracted ${ }^{4,5}$. The first extraction was for $48 \mathrm{~h}$ at $4^{\circ} \mathrm{C}$ with $4 \mathrm{M} \mathrm{GdmCl}, \mathrm{pH} 7.4$, containing $100 \mathrm{mM}$ amino hexanoic acid, $5 \mathrm{mM}$ benzamidine $\mathrm{HCl}, 0.1 \mathrm{mM}$ phenyl methyl sulfonyl fluoride, $1 \mathrm{mg} / \mathrm{l}$ soybean trypsin inhibitor, $0.02 \%$ sodium azide, and $5 \mathrm{mM}$ levamisol. The second extraction was carried out for $96 \mathrm{~h}$ at $4^{\circ} \mathrm{C}$ by using the same buffer containing $0.5 \mathrm{M}$ EDTA. All extracts were concentrated at $4^{\circ} \mathrm{C}$ by ultrafiltration (Amicon YM-5 filter), then dialysed, lyophilized. EDTA extracts were dissolved in $15-20 \mathrm{ml}$ of $20 \mathrm{mM}$ Tris buffer $(\mathrm{pH}$ 8.0) containing inhibitors, placed in a Spectrapor \#3 (cut off $=3,500$ ) dialysis bag, and dialyzed against several changes of $0.1 \mathrm{M}$ formic acid to precipitate proteoglycans and some acidic glycoproteins. The formic acid precipitated material was desalted by Sephadex G-25 and lyophilized. Then quantification of hexuronic acid was carried out for all separated samples by the procedure of Blumenkrantz \& Asboe-Hansen ${ }^{11}$ with Dglucuronic acid as a standard.

\section{Gel chromatography}

To determine proteoglycan size, samples were chromatographed on Sepharose CL-6B column $(1.5 \times 92 \mathrm{~cm})$ and eluted with $4 \mathrm{M}$ $\mathrm{GdmCl}$ in $20 \mathrm{mM}$ Tris/HCl, pH 7.4. Fractions $(3.0 \mathrm{ml})$ were collected and analyzed for hexuronic acid. The material in the 
hexuronic acid containing peak was then chromatographed on a DEAE Sephacel column which was eluted with a linear gradient of 0 to $1.0 \mathrm{M} \mathrm{NaCl}$ in $50 \mathrm{mM}$ Tris $/ \mathrm{HCl}$ buffer, $\mathrm{pH}$ 7.4, containing $4 \mathrm{M}$ Urea. The proteoglycans, which emerged at $0.6 \mathrm{M} \mathrm{NaCl}$, were further purified by gel chromatography on a Sepharose CL-4B column $(1.5 \times 16 \mathrm{~cm})$ eluted with $20 \mathrm{mM}$ Tris $/ \mathrm{HCl}, \mathrm{pH} 7.4$, containing $4 \mathrm{M} \mathrm{GdmCl}$. The final preparation which resulted from these chromatographic steps was desalted, lyophilized and was used for chemical characterization.

\section{Amino acid analysis}

Samples were hydrolyzed in sealed tubes containing $1 \mathrm{ml}$ of $6 \mathrm{M}$ constant boiling $\mathrm{HCl}$ for $24 \mathrm{~h}$ at $108^{\circ} \mathrm{C}$. Analysis was performed on the hydrolysate using an automated amino-acid analyzer (Shibata Chemical Co. Ltd., Tokyo).

\section{Enzyme-linked Immunosorbent assay (ELISA)}

Enzyme-linked immunosorbent assays were performed as described by Rennard $e t$ al. ${ }^{12}$ ) with the following modification. Proteoglycans were dissolved $1 \mu \mathrm{g} / \mathrm{ml}$ in PBS and were coated onto incubation plates, $200 \mu \mathrm{l}$ of solution in each well. The plates were incubated overnight at $4^{\circ} \mathrm{C}$. In some cases, after coating the incubation plate, the antigen was incubated at $37^{\circ} \mathrm{C}$ for $2 \mathrm{~h}$ with $200 \mu \mathrm{l}$ of $50 \mathrm{mM}$ Tris/ $\mathrm{HCl}$ buffer, $\mathrm{pH}$ 7.2, containing $0.03 \mathrm{U}$ per $\mathrm{ml}$ of chondroitinase ABC. Appropriate diluitons of the anti-bovine proteoglycan were made in PBS/azide containing $0.05 \%$ Nonidet P40 and added to the wells and allowed to incubate for 1 to $2 \mathrm{~h}$ at $37^{\circ} \mathrm{C}$. Next, 1:3000 dilutions of alkaline phosphatase-conjugated goat antibody to rabbit IgG were added. After incubation at $37^{\circ} \mathrm{C}$ for 1 to $2 \mathrm{~h}$, the alkaline phosphatase substrate was added, incubation was continued for 30 to $60 \mathrm{~min}$ and the plates were automatically read at $405 \mathrm{~nm}$ with a multiscan plate reader (Titer Tek, Flow Laboratories).

\section{Results}

1. Separation of different density fractions from bovine alveolar bone

The distribution of bone tissue of various densities in terms of dry weight percentage is given in Fg. 1 and clearly shows that bone was a heterogenious tissue, ranging between

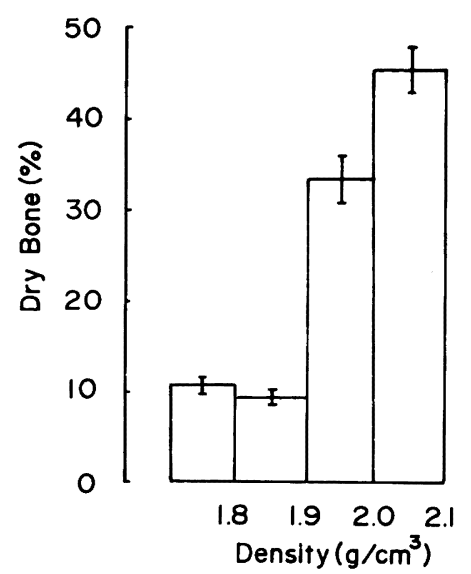

Fig. 1 Distribution of bovine alveolar bone powder among various densities.

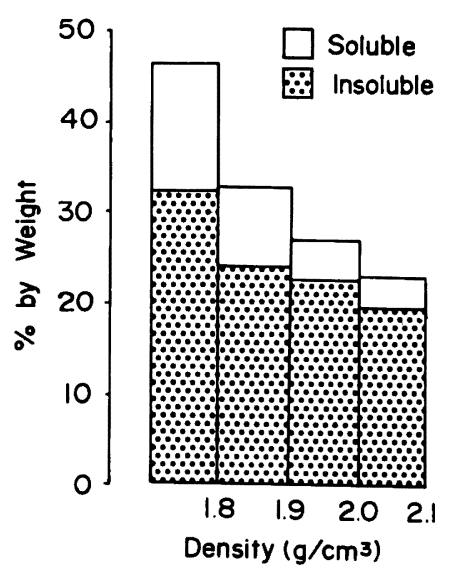

Fig. 2 Organic composition of the density fractions of bovine bone. Soluble components include $\mathrm{GdmCl}$ and EDTA extracts. Note the increasing proportion that insoluble components contribute to the organic matrices as the total organic content falls with increasing density. 
Sepharose CL-6B/4M GdmCl

(A)

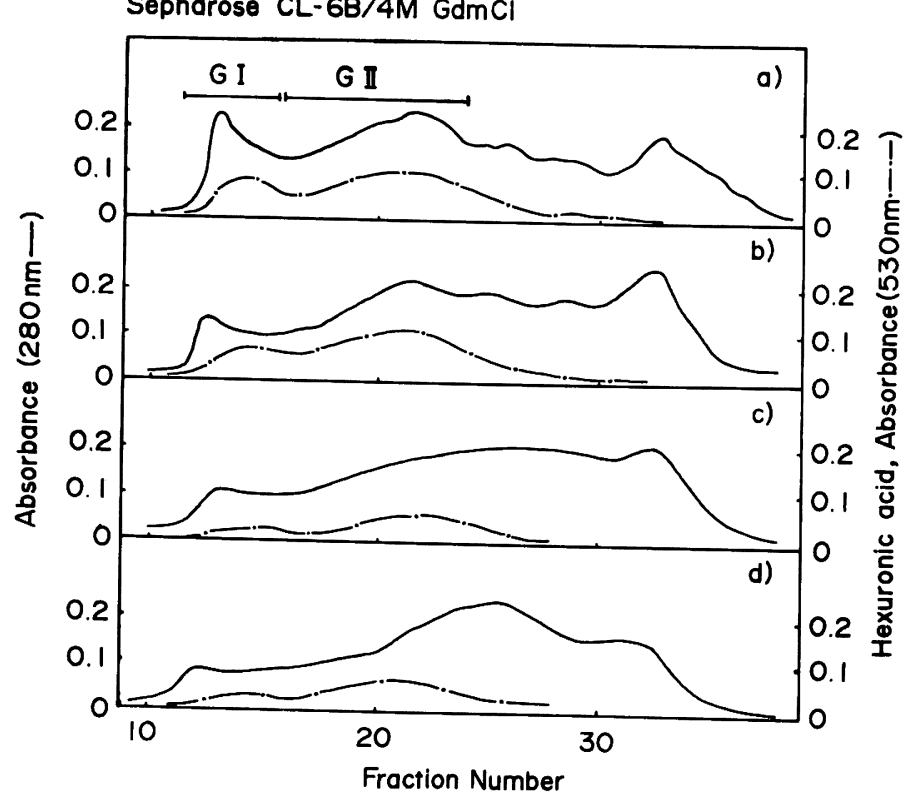

(B)

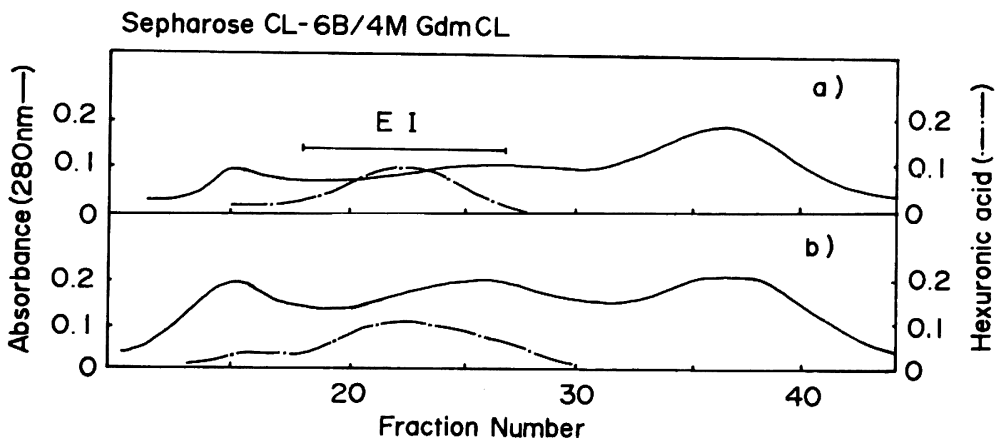

Fig. 3 Chromatography on Sepharose CL-6B of proteoglycan from bovine alveolar bone. The elution was performed under dissociative conditions using $4 \mathrm{M} \mathrm{GdmCl}, 0.05 \mathrm{M}$ Tris/ $\mathrm{HCl}$. Depicted are the elution profile of $\mathrm{GdmCl}$ extracts (A) and HCOOH-Ppt of EDTA extracts (B) ; a) $1.8 \mathrm{~g} / \mathrm{cm}^{3}$, b) $1.9 \mathrm{~g} / \mathrm{cm}^{3}$, c) $2.0 \mathrm{~g} / \mathrm{cm}^{3}$, d) $2.1 \mathrm{~g} / \mathrm{cm}^{3}$. The broken lines indicate hexuronic acid level, and solid lines indicate absorption at $280 \mathrm{~nm}$.

1.8 and $2.1 \mathrm{~g} / \mathrm{cm}^{3}$. The mineral content of bone samples increased with increased density. On the other hand, total organic components decreased with increased density (Fig. 2). Organic components were extracted as follows: First extraction of bone powder with $4 \mathrm{M}-\mathrm{GdmCl}$, and the second with EDTA yielded proteoglycans from non-mineralized region and from mineralized region respectively. The data in Fig. 2 shows the organic percentage of dry bone in soluble extracts as a function of density. There is a significantly greater decrease in the relative concentration of soluble proteins compared 
with insoluble components. Most of the soluble protein consisted of non-collagenous protein. Thus non-collagenous protein decreased with increasing amounts of mineral.

2. Purificaiton of proteoglycans from GdmCl and EDTA extract

The concentration of hexuronic acid per gram of bone in each extracts is listed as a function of density in Table 1 . The hexuronic acid content of the $\mathrm{GdmCl}$ extract decreased from $9.48 \mathrm{mg} / \mathrm{g}$ at $1.8 \mathrm{~g} / \mathrm{cm}^{3}$ to 0.62 $\mathrm{mg} / \mathrm{g}$ at $2.1 \mathrm{~g} / \mathrm{cm}^{3}$. The small hexuronic acid content of the formic acid precipitate of EDTA extracts, also decreased with increasing density. Thus the proteoglycans decreased with increasing amounts of mineral.

The profiles of these proteoglycans with different density are shown in Fig. 3. Gelfiltration chromatography on Sepharose CL$6 \mathrm{~B}$ under dissociative conditions revealed the

Table 1 Hexuronic acid content of organic components

\begin{tabular}{rcc}
\hline Density & GdmCl extract* & $\begin{array}{c}\text { EDTA extract* } \\
\text { HCOOH-Ppt. }\end{array}$ \\
\hline-1.8 & 9.48 & 0.07 \\
$1.9-1.9$ & 4.67 & 0.08 \\
$1.9-2.0$ & 1.35 & ND \\
$2.0-2.0$ & 0.62 & ND \\
\hline
\end{tabular}

* $\mathrm{mg} / \mathrm{g}$ bone.

ND: non detected.

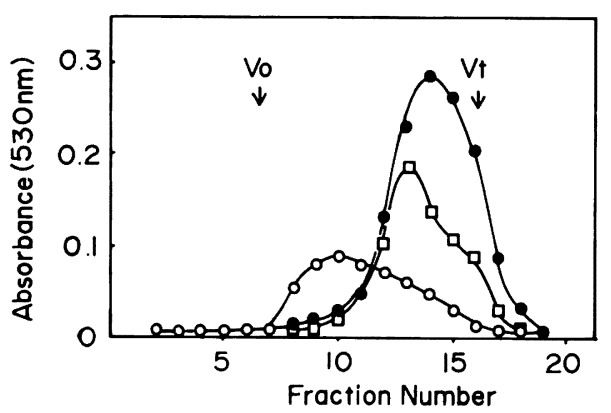

Fig. 4 Chromatography on Sepharose CL-4B of three purified proteoglycans eluted with $4 \mathrm{M}$ Gdmcl, $0.05 \mathrm{M}$ Tris $/ \mathrm{HCl}$ : (O-O) GI proteoglycan (-O) GII proteoglycans ( $\square-\square$ ) EI proteoglycan. presence of two major populations of proteoglycan in the $\mathrm{GdmCl}$ extract (Fig. 3A). The larger proteoglycan eluted at Vo. The amount of the larger proteoglycan (GI) was small and diminished with increasing density. The predominant proteoglycan, which was a relatively small size, remained relatively constant in amount with each density fraction. Proteoglycans released from bone after demineralization with EDTA (Fig. 3B) exhibited only one peak (EI) on Sepharose CL-6B eluted with 4M-GdmCl. This smaller proteoglycan, EI, remained constant in amount with 1.8 and $1.9 \mathrm{~g} / \mathrm{cm}^{3}$ density fractions. These three proteoglycans (GI, GII, EI) were further purified by the following sequentional steps. The material in the hexuronic acid-containing peak was chromatographed on DEAE-Sephacel in $4 \mathrm{M}$ Urea. These proteoglycans, eluted at $0.6 \mathrm{M}$ $\mathrm{NaCl}$, were further purified on Sepharose CL-4B, appeared as identical uronic acid peaks as shown in Fig. 4. Proteoglycan fraction GI, GII, EI were eluted at Kav value of approximately $0.4,0.7$, and 0.7 respectively.

The amino acid compositions of these three proteoglycans are shown in Table 2. GI proteoglycans showed high amounts of gluta-

Table 2 Amino acid composition of bovine alveolar bone proteoglycan

\begin{tabular}{lrrr} 
& GI & GII & EI \\
\hline Hydroxyproline & - & - & - \\
Aspartic acid & 55 & 97 & 91 \\
Threonine & 25 & 36 & 29 \\
Serine & 49 & 52 & 56 \\
Glutamic acid & 91 & 90 & 89 \\
Proline & 103 & 89 & 84 \\
Glycine & 372 & 193 & 114 \\
Alanine & 77 & 55 & 47 \\
Gysteine & 2 & - & - \\
Valine & 30 & 38 & 58 \\
Methionine & - & 8 & 11 \\
Isoleucine & 16 & 56 & 51 \\
Leucine & 38 & 125 & 122 \\
Tyrosine & 8 & 14 & 42 \\
Phenylalanine & 21 & 26 & 51 \\
Lysine & 5 & 13 & 31 \\
Histidine & 65 & 54 & $\mathrm{t}$ \\
Arginine & 47 & 53 & 124 \\
\hline
\end{tabular}




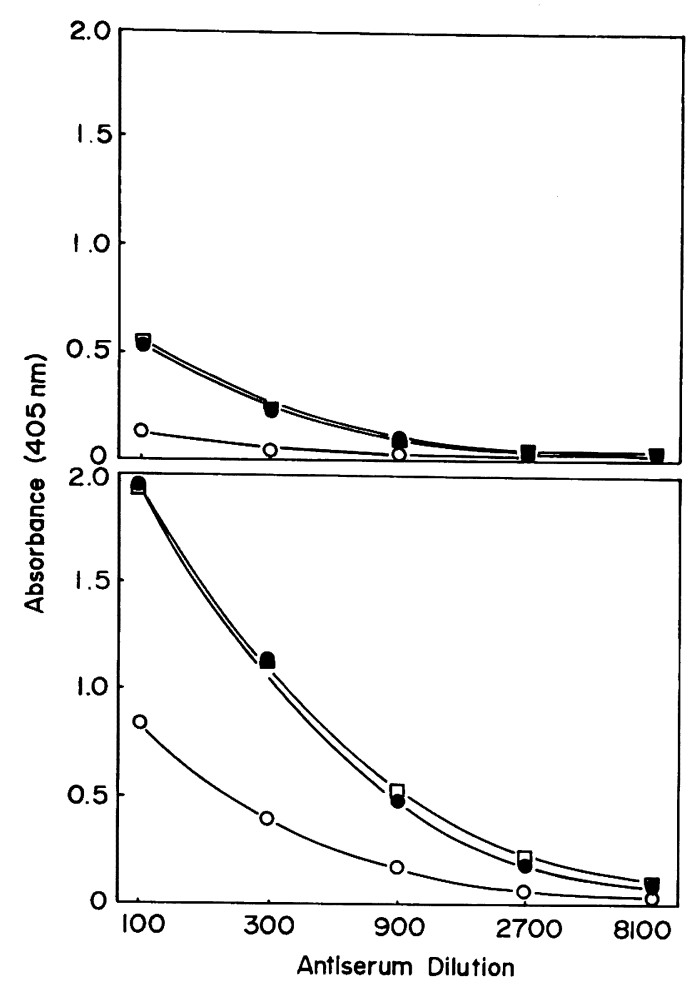

Fig. 5 ELISA for reactivities of different antigens with antiserum to bovine bone proteoglycans. Plates were coated with $200 \mu$ l of a solution containing $1 \mu \mathrm{g}$ per $\mathrm{ml}$ of the test substance. In (B), samples were treated with chondroitinase $\mathrm{ABC}$ as described in experimental procedures. The plates were incubated with increasing dilutions of antisera to bovine bone proteoglycans. Alkaline phosphataseconjugated second antibody (goat anti-rabbit IgG; 1:3000 dilution) was added and the amount of antibody bound to the test substance (released p-nitrophenol) was quantitated colorimeterically. (O-O) GI proteoglycan; (-O) GII proteoglycan; ( $\square-\square$ ) EI proteoglycan.

mic acid, proline and glycine. GII proteoglycan showed high amounts of leucine, glycine and asparatic acid. Amino acids of EI proteoglycan resembled those of GII proteoglycan except for the arginine residue. The composition is similar to the small pro- teoglycan obtained from fetal calf bone, Fisher et $a l .{ }^{6)}$

\section{Immunological relationship}

The three proteoglycans were tested for reactivity with the antisera of small proteoglycan made against bovine compact bone (generously provided Dr. Sato), which did not cross-react with other non-collagenous proteins $(80 \mathrm{~K}, 67 \mathrm{~K}, 60 \mathrm{~K}, 40 \mathrm{~K})$. The antisera cross-reacted with GI, GII, EI proteoglycans, but GI proteoglycan to the least extent (Fig. 5A). The binding to proteoglycans was enhanced five to twenty-fold after chondroitinase $A B C$ treatment of the test material (Fig. 5B).

\section{Discussion}

The present study was undertaken to provide data concerning the alteration of proteoglycan with respect to the mineralization process. The density fractionation procedure can separate various degree of mineralization which allows analysis of chemical studies of bone at the level oi microscopic structure $^{8-10,17)}$. The density range of the alveolar bone was in general agreement with previous studies. About $60 \%$ of alveolar bone powder was located below the $2.0 \mathrm{~g} /$ $\mathrm{cm}^{3}$ fraction (Fig. 1). The density distribution of chick long bones indicated that $40 \%$ of total bone powder was located below the $2.0 \mathrm{~g} / \mathrm{cm}^{3}$ fraction $^{17)}$. This suggests that the alveolar bone consisted of a higher proportion of little mineralized osteons.

The data presented here show that the decrease in the overall protein content of the bone as more mineral is deposited is accompanied by a change in the overall protein composition of the bone; there is proportionally more collagen and less non-collagenous protein with increasing mineralization (Fig. 2). These data provided good evidence that non-collagenous protein are related to the earliest events of mineralization.

Proteoglycans decreased more than total non-collagenous proteins with increasing mineralization. $80-90 \%$ of the total proteoglycan was extracted from the non-mineralized region (extractable with $4 \mathrm{M} \mathrm{GdmCl}$ alone) 
(Table 1). Similar findings have been reported in cartilage calcification ${ }^{1,3)}$. These data support the hypothesis that matrix proteoglycans inhibit calcification and that removal of proteoglycan results in matrix calcification $^{1,3)}$.

Characterization of the three bone proteoglycans in each density fraction was accomplished by gel filtration on Sepharose CL-6B and DEAE ion exchange chromatography. The large proteoglycan (GI) was present only in the non-mineralized region and was similar in size to the fetal, diaphyseal, large proteoglycan reported by Fisher et al. ${ }^{6}$. The small proteoglycans were obtained from both nonmineralized and mineralized regions. With regard to the amino acid composition and size, they are in general agreement with previous studies of bone small proteogly$\mathrm{can}^{6,7)}$. This proteoglycan was smaller than that from cartilage ${ }^{6,7,18)}$. Measurement by ELISA immuno assay showed that all proteoglycans are immunologically similar. This suggests that these three proteoglycans have the same origin, and that small proteoglycan is produced from the degradation of large proteoglycan.

A unique finding in the present study, was the alteration of the proteoglycans in terms of molecular size with respect to density (Fig. 3). The large proteoglycan in the non-mineralized region, diminished with increasing density, while the small proteoglycan in the non-mineralized region is constant in amount with respect to density. This sug- gests that this phenomenon is related to the onset of mineralization. In the mineralized region the small proteoglycan was present only in the low density fraction. These results suggest that the calcification of the alveolar bone is related to the size of proteoglycan and that the large proteoglycan is probably degraded to the small proteoglycan during mineralization. A study of the metabolism of rat proteoglycan supports our data; the large $\mathrm{GdmCl}$ extracted proteoglycan gradually disappeared $24 \mathrm{~h}$ after injection of ${ }^{35} \mathrm{~S}$ radioactivity. Then ${ }^{35} \mathrm{~S}$ was found in the $\mathrm{GdmCl}$ and EDTA extracted small proteoglycan $^{19)}$.

We report here the alteration of proteoglycan during the mineralization process of bone. But there are many other calciumbinding protein (non-collagenous) in bone. Further studies are required to determine the change of other protein during mineralization.

\section{Acknowledgement}

I am obliged to Professor Yoshii Suzuki, Department of Orthodontics, and Professor Shigeru Saito, Department of Oral Biochemistry for giving me helpful advice. I am also grateful for many valuable discussion from the following; Dr. Yoshikazu Iizuka, Department of Dental Health and Public Health, Dr. Margaret W. Neuman and Dr. Toshio Kawase Department of Oral Biochemistry.

Finally, I gratefully acknowledge useful suggestions during this work by Dr. Sadao Sato, and the colleagues of the Department of Orthodontics, Kanagawa Dental College.

抄録：骨有機質中の非コラーダン成分の一種であるプロテオグリカン (PGs) と，骨の石灰化度との関 係を知る目的で, 骨を石灰化の進行状態に応じて分離し, 石灰化の進行に伴う PGs の量的および, 質的 違いを検討した。

実験には牛歯槽骨を用い, 骨の微細構造レベルでの石灰化度の違いを, 微粉化した骨粉の密度の差を利 用して， $1.8 \mathrm{~g} / \mathrm{cm}^{3}$ から $2.1 \mathrm{~g} / \mathrm{cm}^{3}$ の間で 4 つの分画に分けた。各密度分画中の PGs の分離には, グア ニジン塩酸 $(\mathrm{GdmCl})$, EDTA 溶液を用い，非石灰化領域，石灰化領域の PGs をそれぞれ抽出した。そ の結果 PGs の量は密度が高くなるに従って急激な減少を示した。さらにこの PGs の分子量的な差を Sepharose CL-6B を用いて検討したところ GdmCl で抽出される非石灰化領域には, void volume に溶 出する比較的大きな分子サイズの PG (GI) と, 小さな PG (GII, 分子量70 120K) の 2 種類が存在す ることがわかった。しかも GI は密度が高くなるに従い減少することがわかった。一方, EDTA で抽出 される石灰化領域には，小さい分子サイズの PG（EI）しか存在しなかった。

これらのことは, 大きな PG が石灰化の進行過程で分解あるいは変性を受け小さな分子サイズのものに 変化しうる可能性を示唆するものである。そこで, この 3 種の PGs が同一起源のものであるかど5かを, 
アミノ酸分析によって調べた。その結果, 非石灰化領域, 石灰化領域に存在する GII, EI のアミノ酸組 成は，互いにきわめて類似しており，同一の PG である可能性が強く示唆された。さらに，ELISA 法に よる測定では，牛大腿骨から得られた分子量 70 120K の PG に対する抗血清に対し，3種のそれぞれ の PGs は交叉反応を示した。このことから,これら 3 種の PGs は, 本来同一のものであり，GI が分 解，変性を受け GII， EI になったものと考えられる。

以上のことより，骨の石灰化の進行に伴って，PGs はしだいに消失し，分子サイズも小さくなること がわかった。

\section{References}

1) Boskey, A. L.: Current concepts of the physiology and biochemistry of calcification. Clin. Orthop. 157: 225-257, 1981.

2) Piez, K. A. and Reddi, A. H.: Extracellular matrix biochemistry. p. 330-374, Elsevier, New York, 1984.

3) Buckwalter, J. A.: Proteoglycan structure in calcifying cartilage. Clin. Orthop. 172: 207232, 1983.

4) Termine, J. D., Belcourt, A. B., Christner, P. J., Conn, K. M. and Nylen, M. U.: Properties of dissociatively extracted fetal tooth matrix proteins. J. Biol. Chem. 255: 9760-9768, 1980.

5) Rahemtulla, F., Prince, C. W. and Butler, W. T.: Isolation and partial characterization of proteoglycans from rat incisors. Biochem. J. 218: 877-885, 1984.

6) Fisher, L. W., Termine, J. D., Dejter, S. W., Whitson, S. W., Yanagishita, M., Kimura, J. H., Hascall, V. C., Kleinman, H. K., Hassell, J. R. and Nilsson, B.: Proteoglycans of developing bone. J. Biol. Chem. 258: 6588-6594, 1983.

7) Sato, S., Rahemtulla, F., Prince, C. W., Tomana, M. and Butler, W. T.: Proteoglycans of compact bone. Second international conference on the chemistry and biology of mineralized tissue, September, 1984, Gulf shores, Alabama.

8) Richelle, L. J.: One possible solution to the problem of the biochemistry of bone mineral. Clin. Orthop. 33 : 211-219, 1964.

9) Roufosse, A. H., Landis, W. J., Sabine, W. K. and Glimcher, M. J.: Identification of brushite in newly deposited bone mineral from embryonic chicks. J. Ultrastruct. Res. 68: 235-255, 1979.

10) Lian, J. B., Roufosse, A. H., Reit, B. and
Glimcher, M. J.: Concentraitons of osteocalcin and phosphoprotein as a function of mineral content and age in cortical bone. Calcif. Tissue. Int. 34: 82-87, 1982.

11) Blumenkrantz, N. and Asboe-Hansen, G.: New method for quantitative determination of uronic acid. Anal. Biochem. 54: 484-489, 1973.

12) Rennard, S. I., Berg, R., Martin, G. R., Foidart, J. M. and Robey, P. G.: Enzymelinked immunoassay (ELISA) for connective tissue components. Anal. Biochem. 104: 205214, 1980.

13) Pugliarello, M. C., Vittur, F. and de Bernard, B.: Chemical modification in osteones during calcification. Calcif. Tiss. Res. 5: 108-114, 1970.

14) Masahara, S.: Biochemical studies of alveolar bone. Bull. Tokyo Med. and Dent. Univ., 12: 143-158, 1965.

15) Engefelt, B. and Hjerpe, A.: Density gradient fractionation of dentin and bone powder. Calcif. Tiss. Res. 16: 261-275, 1974.

16) Engefelt, B. and Hjerpe, A.: Glycosaminoglycans and proteoglycans of human bone tissue at different stages of mineralization. Act. path. microbiol. scand. sect. A, 84: 95-106, 1976.

17) Lian, J. B., Glimcher, M. J., Roufosse, A. H., Hauschka, P. B., Gallop, P. M., Choen-Solal, L. and Reit, B.: Alternations of the $\gamma$ carboxyglutamic acid and osteocalcin concentrations in vitamin D-deficient chick bone. J. Biol. Chem. 27: 4999-5003, 1982.

18) Heingard, D. and Franzen, A.: Characterization of the major proteoglycan in bone. Second international conference on the chemistry and biology of mineralized tissue, September, 1984, Gulf shores, Alabama.

19) Prince, C. W., Rahemtulla, F. and Buter, W. T.: Metabolism of rat bone proteoglycan in vitro. Biochem. J. 216: 589-596, 1983. 